\title{
Ethnolinguodidactic Approach to Formation of Foreign-Language Discursive Competence of the Bilinguals Based on the Material of Adyghe Folktales
}

\author{
Betti Makhmudovna Dzhandar \\ Fatima Kaplanovna Urakova \\ Asyat Djiraslanovna Loova \\ Marina Ruslanovna Tuova
}

Federal State Budget Institution of Higher Professional Education «Adyghe State University» (ASU) 385000, Maikop, street Pervomayskaya, 208, Russian Federation; Email: nisadgu@yandex.ru

\author{
Doi:10.5901/mjss.2015.v6n5s2p227
}

\section{Abstract}

This paper examines the formation of foreign-language discursive competence in conditions of the national-Russian bilingualism. Conceptual provisions of didactics, linguodidactics, ethnolinguodidactics and theoretical provisions on language and foreign-language education served a basis for the ethnolinguodidactic approach as a productive theoretical foundation for realization of multilingual education. The main attention is paid to interaction and interference of the contacting languages (Adyghe, Russian and English). In the context of this research, it seemed important to consider the issue of the correlation between language and culture which is brightly displayed in verbal communication.

Keywords: language, culture, ethnolinguodidactic approach, national-Russian bilingualism, discursive competence, text, Adyghe folktale.

\section{Introduction}

Highly informative and communicative nature of the modern global community, including the Russian one, necessitates radical changes in the linguistic and intercultural education. Socio-cultural aspect of teaching foreign languages has changed essentially. And this is connected primarily with the basic concept of the linguistic identity, which is a multiaspect structurally ordered set of language skills, namely, production and perception of verbal messages, recognition of various types of speech, adequate to the communicative intention of the speaker, the logical structuring of the selected type of speech and correct the use of linguistic means to solve communicative problem with regard to the communicative situation of the intercourse.

Regulatory framework favorable to the study of foreign languages was created, educational disciplines "Russian Language" and "Foreign Language" were combined in a single educational area "Philology", learning a foreign language from the 2nd class was legislated, the number of hours for teaching foreign languages was increased. However, the level of quality in teaching foreign languages indicates a gap between the "available" and the "proper" state of the main components of the educational process. Our observations and the results of the unified state examination show an insufficient level of the formed foreign-language discursive competence in the bilinguals. Learners use the linguistic means, not matching the message context, they are not able to achieve the objectives of the communicative act, cannot logically and coherently organize their own statement, cannot use such means of lexical and grammatical relationship within a micro text as lexical repetition, synonymous substitution, use of adverbs, pronouns. As a result, the bilinguals' speech appears to consist of separate, unrelated sentences (Dzhandar, 2012). Learners make lexical, grammatical and stylistic errors caused by interfering influence of the contacting languages. What prevents successful combined learning of languages?

The successful solution of the problems encountered is primarily hampered by the fact that the specifics of teaching foreign languages carried out in the conditions of the national-Russian bilingualism is not taken into account. The interference of native, Russian and foreign languages being both positive and negative, is not considered in the teaching practice. Abstract knowledge of the mother tongue, as well as of the Russian and foreign languages is cultivated at school. In our opinion, this is the most inefficient way of teaching the bilinguals a foreign language. In this context, to 
the postulate by N.V. Baryshnikov seems valuable; it states that mastering several languages "implies not isolated processes, but interconnected and interdependent combined learning of several languages by the learners and combined teaching of them by the teachers" (Baryshnikov, 2003). Accordingly, there is demand at the modern school in the national republics for the educational models based on the communicative activity, learner-centered and competency building, ethnolinguodidactic approaches that promote the effective development verbal and cogitative activity in a foreign language with regard to the bi - and polylingual organization of the learner's linguistic identity.

\section{Research Methodology}

Theoretical foundations of learning a foreign language in a bilingual and multicultural environment were laid down in the fundamental works by R.Yu. Barsuk, N.V. Baryshnikov, L.S. Vygotskyy, P.Ya. Galperin, W. Humboldt, T.A. Ilyina, A.A. Leontiev, A.A. Mirolyubov, L.V. Shcherba, Bradford J.D., Schwartz D.L., Van Dijk, Jeremy Harmer, Kang J.Y., Royer J.M., Mestre J.P, Dufresne R.J. and others (Barsuk, 1970; Baryshnikov, 2008; Vygotskyyuй, 1996; Galperin, 1966; Humboldt, 1984; Ilyina, 1984; Leontiev, 1997; Mirolyubov, 2001; Shcherba, 1974; Bradford and Schwartz, 1999; Van Dijk, 1985; Jeremy Harmer, 2002; Kang, 2005; Royer, Mestre and Dufresne, 2005, etc.).

Bilingual education carried out at schools of the Russian Federation can be defined as a positive process of formation of foreign-language discursive competence in the area of general linguistic education, and the systematization of "the ultimate goals of linguistic education in terms of identifying the type of bilingualism helps to coordinate objectives of teaching the Russian, native and foreign languages in each specific case" (Baryshnikov, 2003).

The interaction of different cultures and languages is a distinctive feature of the process of teaching foreign languages in the conditions of cross-cultural communication, which makes linguistic education multicultural, integrated in the multicultural global space and provides representatives of each ethnic group an opportunity to feel their cultural identity. Experience shows that during the interconnected language teaching it is necessary to create polylingual educational systems raising tolerance to different languages and cultures, and their carriers. Combined learning of languages in terms of equal cultural interaction of the representatives of various linguocultural communities, taking into account their singularities and peculiarities, is an essential step in the formation of the learners' interest in languages, cultures and their interaction (Baryshnikov, 2003).

This multi-cultural cooperation should be based on the native culture as a culture of primary socialization; that is why acquisition of any other culture is inevitably going through their correlation. In the process of the combined learning of languages mastering a new foreign-language culture through distinctive features of own ethnic culture under the crosscultural influence of the studied native (Adyghe) and Russian languages creates a specific methodological situation, the successful implementation of which is related to the understanding of the role of each of the interacting cultures and general orientation of this process.

The effectiveness of the foreign-language discursive competence formation depends on such important indicators as the organization of teaching in the mono- or multi-cultural environment, in the mono- or polylingual situation; the sociopolitical factor of learning languages (ethnicity of learners) is equally important. Consideration of these indicators enables to determine the optimal system of linguistic education in the multilingual environment (Sharadzenidze, 1971), to create the ethnic worldview.

From the viewpoint of S.V. Lurie, the ethnic worldview is a structured presentation of the axiological dominants inherent in the culture of a particular ethnic group. At the same time it is emphasized that an individual's vision of the world may be partly conscious and partly unconscious, depending on the (ethnic or axiological) constants which are a basis for this vision formation (Lurie, 1998).

Each ethnic culture has its own logic of development, which helps to establish what is of the fundamental importance and what is of secondary importance. In connection with the above, the ethnolinguodidactic aspect of education is of interest, this aspect cannot be limited only to teaching the mother tongue, it is necessary to make the subjects "Russian language", "foreign language" ethnically oriented. To do this, it is advisable to include ethnic culture in the content of linguistic education.

The ethnolinguodidactic approach is a set of basic principles, specialized methods and specific means forming methodological and technological tools that allow developing scientifically grounded recommendations for the organization of the multilingual education practice: the definition of the strategy and the main methods for resolving them, recording and analysis of the problems of multilingual education and the establishment of their hierarchy, as well as forecasting the prospects of the polylinguistic identity formation on the basis of interconnected learning of languages. 


\subsection{Adyghe folktale as a means to implement ethnolinguodidactic approach in the formation of the foreign-language discursive competence of the bilinguals}

As a means of implementing ethnolinguodidactic approach to the formation of foreign-language discursive competence we have chosen Adyghe folktale being a treasury of culture of each ethnic group, a universal mode to convey certain visions of the surrounding reality and the person, which orients the learning process on the national culture for the purpose of integrative personal education.

An important argument in favor of the choice of folktales was the fact that work on the text of the tales can be conducted in three directions: 1) using folktales as a didactic material; 2) using folktales as a means of helping to organize the explanation of a new material and repetition of the material learned earlier; 3) writing own folktales by the learners. In this regard, in the conditions of linguistic education modernization aimed at the implementation of the standard requirements for the formation of the communicative competence of the learners, the use of Adyghe folktales becomes an effective didactic means of optimizing the learning process (Tuova, 2012).

Being small in size, but having semantic and grammatical completeness, comprehensible by themselves, they are the best object for analysis and for the creative transformation. Work on the texts of folktales enables to achieve implementation of the tasks associated with the increase in both the linguistic and communicative competence of learners, in this case, most importantly, folktale allows organizing educational process as a productive one, aimed at the development of creative abilities. In this regard, Adyghe folktales translated into English are an effective means of formation of the learners' readiness to participate in a real intercultural communication, since they create the actual and verbal basis for the dialogue of cultures. Under these conditions, the importance of the regional component implementation increases in teaching philology to the bilinguals (Tuova, 2012).

Folktales reflect the knowledge, experience and outlook of the people, folk traditions as in a mirror. Usually folktale knows no halftones, it opposes polar qualities: kindness to greed, courage to cowardice, modesty to bragging, honesty to mendacity.

As noted by V.Ya. Propp, a folktale does not come laden with rules of only one nation, it spreads around bringing nations together; traveling around the world (from one ethnic group to another), it is passed from generation to generation (Propp, 2000).

The definition of a folktale given by E.V. Pomerantseva is noteworthy: "folktale is a prosaic artistic narration of magic, adventurous or domestic nature with orientation on fiction" (Pomerantseva, 1965). This refers to such kinds of narratives differing in their genesis, structure, system of images as: 1) animal tales; 2) magic fairy tales or wonder tales; 3) novelistic tales of everyday life; 4) fables; 5) cumulative tales (sometimes also called chain tales); 6) irksome tales.

It should be emphasized that the presence of fiction in the folktale does not deny its connection with life. Reflecting the reality in the fantastic shape and with the help of fantasy, it is facing the future.

Poetical fancies are inherent not only the folktale, but also in other genres of Adyghe folklore. They are present in the heroic "Nart" sagas, in folk tales, in the mythological stories and legends. But in these genres the irreal is less pronounced than in the folktales. In contrast to the folktales, legends and sagas tell of the real events related to a specific time and place of action. As a rule, actors and events in them are not fictitious. The works of these genres differ in composition, language and style.

\subsubsection{Animal tales}

In the fabulous repertoire of the Adyghe peoples animalistic epic stories take a relatively small place. Animal tales make up about a fifth of all recorded fairy plots.

Adyghe animal tales dated far back in the past. They have travelled a long path of development. Originating on the basis of ancient stories and legends about animals, breaking with the old mythological views of primitive people, they turned in a particular genre of oral folk art, transmitted by word of mouth. The heyday of animal tales was associated with the triumph of the worldview that was free of religious, animistic, ritual and magic concepts and ideas. At various stages of the historical development the social functions of the animal epic were changing, in accordance with this its plots, themes, ideas and images were transformed.

Social allegorism is the most vivid and characteristic feature of Adyghe animal epic: its heroes are animals endowed with human traits, who often lead lifestyles similar to the social life of people. This category of folktales is characterized by the narrative "The Doe-hare, the Fox and the Wolf" (Hut, 1973). The folktale depicts social relations in the Adyghe feudal-patriarchal society.

It is characteristic that in the folktale the groups of strong and weak animals are contrasted. The weak ones are 
described to be kind and sensitive, helping each other. As opposed to them the strong predators are endowed with negative traits: they are greedy and hypocritical, cunning and cruel, that is why the plots of these folktales differ in thrilling dramatism and fast-flowing action. This explains the absence of fairy ritualism in the animal epic, the widespread use of imaginative possibilities of oral speech and dialogical forms of narrative.

Animal tales with a pronounced social-accusatory orientation emerged in the Adyghe folklore relatively late. The blossom of these folktales, most probably, refers to the period of exacerbation of the class struggle in the Adyghe feudal society. That is why the social and class motives can be clearly traced in them, social evils and moral statutes of class society are sharply castigated.

It should be noted that the Adyghe folktales about animals often have the character of the parable. They contain morality and edification. Arising from the narrative plot, the statements are expressed in the form of proverbs in many folktales.

\subsubsection{Magic fairy tales}

Adyghe magic fairy tale has roots stretching back into antiquity and reflects the mythological visions of the ancient people. Unravelling of the plot Adyghe wonder tale is associated with a variety of topics. The desire to go to the unknown lands, to find people who are stronger and more courageous than the heroes, to try their strength, to get some remedy for the parents, to find happiness and wealth, to perform a difficult task of the Prince or the beloved girl, to release the oppressed from the power of the cruel and treacherous Prince or Khan, to defend freedom and independence of the native land and much more in the same strain - these are the themes of Adyghe magic fairy tale narrations. The Adyghe fabulous repertoire is rich in folktales about heroic rescuing of the bride by the main hero (Cienki, 1997).

Adyghe wonder tale expresses moral ideals of its creators. The topic of labor is one of the major themes of the Adyghe magic epic. It determines the nature of narration as well (Hut, 2003).

Generalized image of the protagonist is inherent in the Adyghe magic fairy tale. Usually he had no specific proper name, though in later folktales the names sometimes were given.

Adyghe magic fairy tales are rich in positive female characters, and they are more diverse that the male ones. Each heroine has her own unique features, touching and captivating the listener. Almost all women are fabulously beautiful; many differ in great intellect and have heroic might.

It should be stressed that in the wonder tales the image of the princess or Khan's daughter is characterized by the same features as their counterparts of peasant origin. The princess is as kind, wise and hardworking, loyal and patient as a country girl.

In contrast to the images of the protagonist, his beloved, their assistants forming a bright, cheerful fairy-tale world, Adyghe folktales portray their enemies constituting the dark world. First of all, these are fictitious beings, villains: иныжъ (a giant), блэгъожъ (a dragon), алрэгь-алрэгужъ (the magic carpet), цэ1унэжъ (a witch), and the hero's social enemies - khans, princes and noblemen (uorki).

Many Adyghe magic fairy tales are characterized by complex composition containing several "stages". The narratives are sort of "a folktale in the folktale": a number of tales is inserted into the main text. As a rule, they are closely related, densely interwoven into the main plot and bear the necessary ideological and artistic load entirely determined by the intention of the main folktale.

Adyghe wonder tale, as a rule, ends with the triumph of justice and the victory of good over evil. Also the ending is widespread, in which the narrator pretends to be an imaginary eyewitness.

A characteristic feature of Adyghe magic fairy tales is the presence of peculiar questioning endings directly related to the narrative. Proverbs and sayings are also used as a conclusion or morality.

\subsubsection{Novelistic tales of everyday life}

Adyghe folktale of everyday life, like a novella, is a short story about a fun and unusual everyday incident, characterized by the exigencies of the plot unravelling, the clear composition and elegant artistic form. Eventfulness, conveyance of the hero's state through actions and deeds, the lack of descriptiveness, etc. are characteristic features of the tales of everyday life and novellas.

The Adyghe people have widespread social and family tales of everyday life. By of adjacent Novelistic narratives about smart answers about the cunning fellows, about fools, about astucious thieves, human vices and virtues join to the folktales of these major groups

Adyghe folktales of everyday life are characterized by uniqueness of the artistic form. They are not marked by fairy 
ritualism peculiar to the magic fairy tale, they are deprived of the traditional sayings, standard beginnings and endings, threefold repetition of scenes, typical verbal formulas, and so on occur less frequently in novelistic tales than in wonder tales. F. In the vast majority of Adyghe tales of everyday life set-up is of real nature.

Humor is one of the characteristic features of novelistic tales of everyday life. As a rule, the comic occurs when a folktale portrays unrealistic positions and situations. The comic is often created when an antagonist, a rich and noble man, does not know the basic things and, therefore, does stupid things. The story of the good/bad wives; the improvement of lazy, obstinate, unfaithful wives is used very often.

The lexicon of Adyghe tales of everyday life is characterized by a certain emotional coloration created by the use of synonyms, the predominance of colloquial, everyday and common words. However, conciseness and intensive statement of content is more common to the everyday life epic.

\subsubsection{Fables}

Adyghe fables are entertaining stories about the incredible adventures of the narrator, who tells them as an unmitigated fib, a lie. In terms of volume, these are small prose works deprived of descriptiveness, digressions and repetitions. The action takes place in them quickly, without slowing down and stopping. They have no sayings, beginnings, endings, traditional formulas and platitudes that are typical of the compositions of the above kinds of folk tales.

Fables develop observation, wit and insight of the listeners. Entertaining nature, easy humor, exaggeration of events, facts, objects and phenomena are their most characteristic features.

\subsubsection{Cumulative folktales}

Adyghe cumulative folktales have a certain sense and great educational value. They demonstrate somewhat simplified, but true depiction of the phenomena in their relations and development. Events described in the chain-like narratives are related to the labor activity and labor relations of people.

The absence of conflict is one of the characteristic features of Adyghe cumulative folktales. Their plots are based not on collision and the armed struggle of enemies, but on the protagonist's desire to rescue his companion who had got in trouble ("The Flea and the Lice"), to clarify the correlation of certain characteristics of objects and phenomena - who is stronger? who is bigger? etc.

It should be underlined that the peculiarities of the poetics of cumulative folktales contribute to their rapid memorization and subsequent accurate retelling; in fact, this is what they have been created for.

It should be said that the number of cumulative tales in the folk prose of the Adyghe peoples is small. The simplicity and clarity of the plot, the comprehensible content, and vivid imagery presentation make us think that they were intended primarily for the children's audience as similar tales of other nations.

\subsubsection{Irksome folktales}

The so-called irksome folktales and nursery rhymes occupy a special place in a fairy-tale epic of the Adyghe peoples. They have the character of humorous sayings, catch-phrases and are built on a play of words.

Irksome folktales tell us about the most incredible and even unimaginable events, the reality of which cannot be believed.

Irony and light humor are characteristic features of irksome folktales. This is traced in the selection of fairy-tale characters, actions, and deeds of fairy-tale characters. Most often, household items or food appear in them as the protagonists. Pedagogical orientation irksome tales is obvious. Despite the simplicity of their content and artistic form, they are expanding the horizons of children, promote their personal enrichment, and teach them the quick-wittedness and mental aptitude. Undoubtedly, these works of the fabulous epic were a part of the arsenal of Adyghe folk pedagogy.

Adyghe folktale characterized not only by a deep ideological and thematic content, but also by high artistic merits. It is in a certain relationship with other genres of folklore, it is especially close to the prosaic genres. Connection of the fabulous epic with other types of oral-poetry is expressed in common plots, images of characters, in the similarities and differences between poetics and traditions of existence and performance. Thus, the presence of fiction brings folktale closer to the sagas and heroic epic of the Narts. It differs from these genres in its character and quality of fiction. Common motives (about the miraculous birth of the hero, trial of his heroic might, invulnerability of his body), the common characters (giants, dragons and other monsters), the way of life bring together the magic and epic tales with pshchynatls (folk poems) and sagas about the Narts. The apparent activity of miraculous powers in a wonder tale and humanistic 
optimism distinguish irksome folktale from many genres of folklore (the Nart epic, historical and heroic songs, and sagas). Relationships of folktales with small genres of Adyghe folklore, in particular, with the proverb, are manifested in the widespread use of proverbs, in their expansion to the size of a fairy tale, and vice versa.

\subsection{Correlation of notions 'language - history and culture of ethnos - history and culture of other nations'}

In the process of formation of foreign-language discursive competence in the conditions of Adyghe national school based on the material of Adyghe folktales it is also important to determine the correlation of the simultaneously studied languages.

The basic condition for the formation of foreign-language discursive competence of the bilinguals should the trilingual experience of the learners, its dynamic nature, which leads to the permanent change in the level of the formed proficiency in each of them. And these changes entail growth of the volume of associative supports. Particular attention is deserved by the processes of formation of the actual level of the learners' speech and the establishment of the zone of proximal development, implying the start and development of the long-term level of speech (foreign-language speech developing through the Russian language). And the level of the learners' actual speech includes already developed speech skills in the native and Russian languages, established in the previous years of studying (Dzhandar, 2012).

The perception of a word in this context creates the prerequisites for understanding the life, history, material and spiritual wealth of the people whose language we study. Being convinced that the correlation of notions "language - the national history and culture - the history and culture of other nations' is important not only in terms of the linguistic aspect, but also in the ideological one, R.A. Budagov noted that the complex multidimensional picture of the word life reflects the life of the society, life of the nation, comprehension of which usually begins with the comprehension of the language of this nation (Budagov, 1988).

L.V. Shcherba in his time also pointed out that content plane of the words certainly includes ideological components, semantic parts conditioned by the world outlook characteristic of the given ethno-cultural community. "After all, ideology must affect not only a part of the glossary, but in translations as well, and it is certainly the most important, but also the most difficult question. In fact, a lot of our concepts have changed in their content, but how can we reflect this simply and clearly in the translation?" (Shcherba, 1974). It is non-conceptual semantic parts of the familiar words meant by L.V. Shcherba that allow entering into another national culture, the ethno-cultural community environment.

Along with the general denotative (as well as connotative) meaning the words acquire shades of meanings, which are the result of existence in the national-specific social usages, in the national-specific social way of life. At the same time, they represent the 'non-conceptual semantic parts', semantic background, due to which the language acts as one of the guardians of spiritual values of the national culture. Thus 'background lexicon' is formed, reflecting the national identity of perception by one or another ethnic group of natural phenomena, social life, familiar to all nations, but differently understood by them.

\subsubsection{Non-equivalent and background words}

In addition to the equivalent background lexicon cumulative ability of the language is clearly demonstrated and displayed by non-equivalent vocabulary, the content plane of which cannot be compared with the semantics of any foreign words. Non-equivalent vocabulary (or untranslatables) does not have adequate verbal correspondences in other languages. Non-equivalent and background words mark all the most significant in the past and present of any nation, all its achievements and losses on the centuries-old path of development, its views, estimates, and judgments. This category of lexicon reflects:

1) nationally biased units of everyday life: a) dwelling, property (1анэ, хьак1эщ; izba, avoska; pub, sporran); b) clothes, headware (саe, цые, к1ак1о; kokoshnik, shapka-ushanka, kosovorotka; kilt, Oxford shoe); c) food, beverages (щыпс, бахъсым; borsch, vodka; pudding, whiskey); d) kinds of labor and occupation (ш1ыхьаф; Subbotnik; back benching); e) monetary units, units of measurement (сом, чапыч, залэ, т1уалэ; rouble, kopeck, versta; pound sterling, penny, mile); f) musical instruments, folk dances, songs, performers (шык1эпщын, зэфак1y; balalaika, 'Tsyganochka', A.B. Pugacheva; mouthorgan, "The Highland Fling", Sir Elton John); g) folk holidays, games (пхъэк1эн, ашрай; Maslenitsa, gorodki; Thanksgiving, golf); h) forms of address (зиусхьан; gospodin, grazhdanka; Sir, Missis);

2) ethno-graphic and mythological realias: a) ethnic and social communities and their representatives (шапсыг,, бжъэдыгъу; the Adyghe, the Dagestani; the Welsh, the Irish); b) deities, fictitious beings, legendary places (Ахын, исп, иныжъ; Perun, Koshchei the Immortal, Velikiy Ustug; puck, changeling, Stonehenge); 
3) realias of the natural world: a) animals (мышъэ, тыґужъ; sobol; grizzly); b) plants (зэрыджай, п1ырып1; landysh [lily-of-the-valley]; shamrock); c) landscape (шъоф, хашъо; steppe, tundra; bush, highlands);

4) actual and historic realias of state administrative arrangement and social life: a) administrative units and state institutions (къэралыґу; Federal Okrug; county); b) public organizations, parties, etc., their functionaries and participants ('Yedinaya Rossiya', V.V. Zhirinovskyy; Republican Party, Gordon Brown); c) industrial and agrarian enterprises, trading establishments (тучан; kolkhoz; drugstore); d) basic military and police units and ranks (FSB; Pentagon); e) civil offices and occupations, titles and statuses (к1элэегъадж, псэолъэш1; docent; cowboy);

5) onomastic realias: a) antroponyms (К1эращ; Ivanov, Petrov, Sidorov; Smith, John, Green); b) toponyms (Шъачэ, Ц1эмэз; Moscow, Arbat; New York, Oxford Street); c) names of the literary heroes (Гулэз, Анцокъу; Oblomov, Chatskyy; Othello, the Foresights); d) names of companies, museums, theatres, palaces, shops, airports, etc. (Gazprom, the Hermitage, MKhAT, Petrodvorets, GUM, Domodedovo; BBC, Tiffany's, Heathrow);

6) associative realias: a) vegetative symbols (чъыгай, чэрэз; oak implying wooden-head, turnip associated with head; rose, shamrock); b) animalistic symbols (мышъэ, пцэжъый; bear, golden fish; bee, turkey); c) color symbolism (фыжьы, ґъожьы, шэплъы; krasnye i belye [the white and the red]; green (St. Patrick's Day), white and red rose); d) folklore, historical and literary allusions ("Noch. Party. Partyzany" hinting at "Noch. Ulitsa. Fonar. Apteka" [Night, street and streetlight, drug store] by A. Blok; Camillagate - a hint at Watergate scandal relating to the impeachment of President Nixon); e) language allusions (soft landing to your batteries - hint at wishing pilots good soft landing; "Big Brother"- name of the British reality show referring to the corresponding phraseological unit meaning supervising government).

\subsubsection{Correlation of notions of different languages}

In view of the above, we represent a classification consisting of four variants of correlation of concepts of different languages:

1. The volume of concepts coincides completely. This applies to all personal names and the majority of terms (Great Britain, Rostov-on-Don, New York Times, BBC, allergy). In this case, one just needs to replace a word of one language with a word of another language.

2. The volume of concepts in one language is wider than in the other. In each language the vast majority of words are multivalent. At the same time the word can have one foreign-language equivalent according to the central meaning and another equivalent for other peripheral meanings (teenager - youngster, club recreation center, society).

3. The volume of concepts in two languages coincides partially. Such interaction is the most widespread, because each language has developed in its own way, and in every language there appeared unique concepts inherent only in it (head, car).

4. The volume of concepts in two languages does not coincide. Many international words, going back to a common root, in the modern languages have totally different meanings (ammunition - armament, instead of accoutrements, equipment; cutter - in English the primary meaning of this word is a 'person, machine, or tool that cuts something', whereas in Russian kater means small sailing boat or armed vessel, which is a secondary meaning of this English word). There are also cases when in the course of the word development its spelling (or pronunciation) approaches the spelling and pronunciation of the word in another language. This is so-called pseudo-international vocabulary (cask - a barrel, not the helmet, kaska in Russian).

\subsection{Text as a product of oral activity}

Considering philology as an aggregate of sciences studying the essence of the spiritual culture of human society, expressed in the language and literary works, literary education is aimed at creating a wide range of humanities knowledge, as well as skills and abilities to work with the text. This knowledge, these skills and abilities, as well as certain personal qualities make foreign-language discursive competence, which is an essential component of communicative competence. The text is the center around which the entire system of education is built (Jeremy Harmer, 2004).

It should be taken into consideration that text is used for educational purposes and as a goal of education (learning the correct construction of the text in accordance with the communicative pragmatic task) and as a means of learning (the source of language material for teaching speaking and writing, the source of expansion and improvement of linguistic knowledge; motivation to personal self-development (Belyaeva, 2009). 
Summarizing the linguistic concepts, it should be noted that under the text is understood of a speech formation consisting of two or more text units (quotations, textemes, speech acts), which are interconnected by means of special means. And in addition to a quantitative criterion it is required to take into account the notional (semantic) criteria. This refers to the concept of coherence (semantic connectivity and the concept of the coherent whole), introduced by German scientists Robert-Alain de Beaugrande, and Wolfgang U. Dressler, who formulated seven criteria of textuality (Beaugrande, Dressler, 1981).

Without entering into polemics with the authors of this theory, we point out only that following domestic linguists I.R. Galperin, O.I. Moskalskaya (Galperin, 1981/2001; Moskalskaya, 1981), we recognize the cohesion and coherence of the text as its conventional, undeniable signs, considering such features of the text as the informativity, situationality, intentionality taken for granted or optional (intertextuality).

In this context, the analysis of the text construction rules in the simultaneously studied languages is valuable, it proves that the construction of the text (micro-text) has the common patterns: firstly, the micro-text of the compared languages is based on the following scheme: the beginning - the main part - the ending; secondly, there is a coincidence in the types of a complex syntactic whole in terms of structural and semantic characteristics; thirdly, during text construction similar means of connection between the micro-text components are used: conjunctions, lexical repetition, pronouns, synonymic and antonymic substitution, tense and voice forms of verbs-predicates; fourthly, similar types of texts are observed in the simultaneously studied languages: description, narration, reasoning.

There are important differences in the construction of the text in the compared languages that are related to the structural features of a simple two-member declarative sentence in the Russian, Adyghe and English languages, which is mainly connected with the difference in the order of words in a simple sentence. This is explained by the fact that Russian, Adyghe and English belong to different linguistic systems: Russian is an inflected language, Adyghe and English are agglutinative languages (Shkhapatseva, 2005).

The conclusion that different systems of the contacting languages cause interference phenomena occurring during mastering the mechanism of own text construction by the bilinguals seems valuable.

\section{Methods}

Currently the formation of foreign-language discursive competence of the bilinguals is understood as the formation of the learner's personality, able to participate in the indirect and direct communication at the cross-cultural level. According to N.D. Galskova, this refers to the formation of learners' "basic features of the secondary linguistic identity, which in aggregate make the complicated integrative whole facing not only communicative, but also intercultural competence" (Galskova, 2000).

Ethnolinguodidactic component of the second language learning content that introduces learners to the history and contemporary realities of the studied language-speaking country, various aspects of the lives of their peers, deepening and differentiating the learners' vision of the surrounding reality, namely: everyday life (food, drinks, national holidays and other), living conditions (standard of living, living conditions, etc.), interpersonal relationships (in the family and so on), the core values, beliefs and opinions, body language etc., helps in the selection of teaching content, implementing topical and procedural sides of speech activity: "1) phonetic, lexical and grammatical, linguistic and cross-cultural means of communication; 2) knowing how to use these means in the process of intercultural communication; 3) skills and abilities, which are formed in the learning process and provide an opportunity to use language as a means of communication; 4) implementation of subject-content aspect of communication (spheres, themes, communication situations); 5) history and culture, representing the material basis of the education content" (Urakova, 2010).

The selection of the content of foreign language teaching is carried out based on such principles as communicative and motivational orientation, situationality, informativity, high educational value, authenticity, functionality and availability. It is important for the selected material at each stage of learning to stimulate learners to implement communication in the situations of intercultural communication. In connection with the above, one of the determining factors in the creation of an effective methodology is the consideration of the principle of cross-cultural interaction, which in the process of foreignlanguage discursive competence allows seeing the learners' achievements in mastering the studied language at the socio-cultural level. As a result, the following shall be provided:

1) acquisition of knowledge about the linguistic view of the world (description and expression of own attitude to the linguistic view of the world by the means of the studied language);

2) digestion of background knowledge from the sphere of life of native speakers as semantic associations and connotations, providing normative character of verbal communication in the cross-cultural interaction;

3) broadening of the learners' general outlook, that is the knowledge of names, dates and events ensuring the 
effectiveness of communication in the new language environment (Yelizarov, 2005).

Methods of teaching are the most important component methodology. The teaching method is a "system serial impact of the teachers and the learners, aimed at organization of mastering all the elements of educational content" (Vinogradov, 1956).

Methods of teaching a foreign language can be divided into two groups: communicative and non-communicative ones.

The communicative method refers to productive forms of work having a problematic, investigative nature in the process of teaching production and reproduction of speech. A.N. Shchukin states that the method is based on the ideas of communicative linguistics, psychological theory of activity, the concept of individuality development in the dialogue of cultures. The latter determines the ultimate goal of teaching a foreign language - to develop foreign-language discursive competence; to develop and bring up the pupils by means of a foreign language (Shchukin, 2010).

Communicative method based on the following methodological principles: "1) speech-oriented teaching; 2) consideration of individual psychological characteristics of the learner with the leading role assigned to his personality aspect: the ability to acquire the language (a kind of memory, the level of phonemic hearing, ability to generalize, and so on); abilities to perform certain activities, i.e. the ability to learn (higher level of abilities provides greater willingness to actively participate in the activities); personal properties according to interests, outlook, position in the team of learners; general intellectual abilities (inherited or acquired); inherent preferences in the collection of information (visual, auditory, motor); the dominant character of the cerebral hemispheres (the left shows the aptitude to analyze, right is responsible for the aptitude to synthesize); sensitivity to the environment (comfortable conditions of learning); 3) verbal and cogitative activity as the constant involvement of learners in the process of communication in direct (verbal) or indirect (mental) form; 4) the systemic-functional approach to the selection and presentation of educational material at all levels: lexical, grammatical, situational, thematic; 5) situationality of the learning process, considered both as a way of verbal stimulation and as a condition for the development of speech skills; 6) problematicity as a way to organize and present educational material"(Shchukin, 2010).

The established objectives of teaching, formulated principles of non-native language teaching are implemented in the system of exercises, which is one of the most important components of any methodical system.

With regard to the data of linguistic studies of the hierarchically structured text and micro-text (a complex syntactic unit) it proved to be "reasonable to distinguish the following levels in the work on the text of folktales: semantic- logic, linguistic, verbal and communicative. Within each level of the work on the text in accordance with the requirements of linguodidactics a certain consistency is adhered to in the implementation of the systemic work, including receptive, reproductive and productive exercises (conditionally verbal, properly verbal and communicative ones)"(Urakova, 2010).

Semantic-logic level involves the use of receptive exercises (reading the text, dividing it into meaningful parts, selection of names for each of them; distinguishing the primary and secondary information; determining the idea of the text; determining the sequence of actions); reproductive exercises (making a sentence of these words; restoring the logical sequence of sentences, meaningful parts of the text).

At the linguistic level receptive exercises are used (name the means of connection between the sentences; find the sentence that serves for connection of the semantic parts of the text); reproductive exercises (insert the missing means of connection in the text; replace the repeated means of connection with the other one); productive exercises (select introductory or concluding sentences omitted in the folktale text; answer the question - how does the folktale begin and end?; compare the folktale with the tales of other nations; make summary of the read folktale). "The verbal level implied usage of conditionally verbal exercises (comment on the following statements taken from the text; using facts from the folktale, tell us about ...; convey the basic idea of the fairy tale in a few sentences); properly verbal exercises (make up micro-texts based on a series of pictures, based on the key words; retell the folktale in your own words (with variations, with the subsequent assessment, with the elements of the reasoning)).

At the communicative level, the following tasks were used: 1) make a story based on the given beginning; 2) express your attitude to the read; 3 ) how do you understand metaphoricity of the folktale, give examples of life; 4) express your opinion on the following statement: Where there are no good oldsters, there are no good youngsters.), etc." (Dzhandar and Tuova, 2007).

A set of exercises based on the material of folktales provides the transition from understanding the text at the level of meanings to the understanding at the level of sense through the level of in-depth understanding.

\section{Results and Discussion}

In the search for the ways of efficient formation of foreign-language discursive competence, summarizing the material on 
foreign language teaching, a number of teachers point out that the work on the connected text is carried out mainly in terms of understanding by the learners of the content of the finished text and its reproduction; the tasks to make up a connected statement based on the keywords and without them do not teach to use the mechanism of the text (micro-text) construction. Unfortunately, inter-level connections are not taken into consideration in the language for targeted propaedeutic work on the development of the learners' speech. To study a foreign language effectively is only possible with regard to the learners' bilingual experience. However, the bilingual experience is considered by the teachers very rarely. Exercises with the task to make up own connected statements are given without proper preparation, so the learners' statements, even made by analogy with the read are characterized by logical spontaneity, fragmentarity, incoherence of speech, which is confirmed by the questionnaire survey conducted in the schools of the Republic of Adygea. The survey involved 15 teachers in order to study the state of work on the formation of foreign-language discursive competence of the learners, teachers were offered the questionnaire.

The questionnaire survey was also conducted in high school to identify the students ideas about the role of the native, Russian and foreign languages and the importance of having discursive competence.

$50 \%$ of respondents stressed the importance of simultaneous studying of the native, Russian and foreign languages in the development of international contacts. $80 \%$ of the students confirmed the necessity of mastering a foreign language for a successful career. 76\% reported increased interest in learning foreign languages, which is promoted, in their opinion, by the intensive learning, lessons in multimedia audience, use of authentic cross-cultural materials, as well as a friendly atmosphere in the classroom. However, $24 \%$ of the learners indicated the lack of information about the daily life of the British, the customs and traditions of the English society. $48 \%$ of respondents drew attention to the lack of professionally significant information about the political and economic situation in England, linguistic and verbal means of communication in the employment-related situations, the organization of working time, information about the rules of business communication. In the opinion of the majority of students (92\%), the introduction of modern textbooks and manuals containing the above information, the use of interactive forms of work (role playing, presentations) in the teaching process contribute to increase motivation to learn foreign languages.

When questioning the teachers of the native, Russian and foreign languages, we were interested in three parameters: 1. The level of methodical awareness of teachers about the work of leading scientists working in the field of speech development methodology, who made a significant contribution to the theory and practice of teaching the native, Russian and foreign languages. 2. Typical difficulties faced by teachers in the process of formation of the foreign language discursive competence. 3. Work experience (belonging to one of the four distinguished by us employment groups: the first - at least 3 years, the second - from 3 to 5 years, the third - from 5 to 10 years of experience, and fourth more than ten years).

As to the first parameter, in general the questionnaire revealed a sufficient level of methodological knowledge of the teachers surveyed. Thus, the awareness factor as the ratio of the number of named authors - experts in teaching methodology to the optimally sufficient quantity of them, being equal to 15 , makes 0.57 in this group (which is by 0.5 greater and may be considered a positive fact). When teachers were asked to report on the authors - experts in teaching methodology, whose work on the development of speech are known and used in the work, it was found that at an average the teachers named 9 of the best-known to them authors. So, $53 \%$ of respondents are aware of the work of almost all the authors of the proposed list. In the field of psychology the best known are the works of L.S. Vygotsky, A.A. Leontiev and others. Almost all respondents (72\% to $80 \%)$ are aware of and use the works of well-known scientistsmethodologists, N.D. Galskova, A.N. Shchukin and others. In the field of foreign language teaching methodology the works by R.Yu. Barsuk, N.D. Galskova, A.A. Mirolyubova, V.V. Safonova and others are best known for the teachers.

Information about the methodical awareness of teachers was analyzed depending on the length of work experience. Thus, it has been found that there is a certain (not strong) direct connection between the length of work experience and the level of methodological awareness of the teacher (correlation coefficient $=0.15$ ). At an average the length of employment of the teachers surveyed was equal to five or more years. In this case the average number of authors, named by teachers, was nine. This fact indicates sufficient awareness and experience of this group of teachers, which enables to trust their conclusions and assessments. This is also confirmed statistically: the data on these two parameters in a sample group of teachers are homogeneous (coefficients of variation, i.e. the measures of the data spread are small $-42 \%$ and $33 \%$ ). Work experience coefficient as a ratio of the experience grade of a particular teacher to the greatest work experience grade (4) is above the satisfactory one and makes 0.7 . Coefficient of awareness in this case also exceeds 0.5 (above the satisfactory one) and is equal to 0.57 .

Identifying the level of difficulties the teachers face in the process of foreign language teaching, it was proposed to choose four common problems: 1 ) the problem of enriching vocabulary; 2) formation of the communicative competence; 3 ) issues of speech culture; 4) issues of perception and understanding of speech. 
The analysis of the obtained results of the survey show that the learners have the greatest difficulty in the work on the perception and understanding of speech (the problem of conscious reading, understanding the meaning of words, the meaning of the text, etc.). This was said by $48 \%$ of teachers. The second place is taken by the problem of oral speech formation as a whole (the $44 \%$ of respondents experienced difficulties). The issues of speech culture (work on pronunciation and accent rules, rules of word usage, speech ethics, etc.) cause difficulties for $36 \%$ of the learners. Almost a third of respondents (32\%) designate the formation of foreign-language discursive competence among the problematic issues.

As a result, we can state that in the process of teaching the bilinguals a foreign language experience all teachers experience definite difficulties, but to different extents. It was noted: the longer work experience, the less difficulties are experienced by the teachers (correlation coefficient $=-0.1$ ); the greater methodological awareness of the teacher, the less problems are encountered in the formation of foreign-language discursive competence of the bilinguals (correlation coefficient $=-0.2$ ).

Deficiency of papers containing theoretical justification and practical implementation of the ethnolinguodidactic approach to the formation of foreign-language discursive competence by means of the native, Russian and English languages has identified the need to create a conceptual linguodidactics model.

To test the effectiveness of the developed model the experimental teaching of learners of national school was conducted.

Formed foreign-language discursive competence of the bilinguals was determined by the combination of the following criteria: 1) the effective use of writing as a means to carry out teaching, vocational-oriented and self-education activities; 2) improvement of the qualitative characteristics of the written text; 3) the variety of the involved situations of formal and informal nature; 4) greater complexity of the produced texts; 5) expansion of themes and problems of communication; 6) a high degree of independence and activity of the learners.

As the experiment showed, the level of the formed foreign-language discursive competence of the students in the experimental classes was by 20-30\% higher than in the control classes.

Based on the results of the knowledge acquisition test it can be reliably stated that by the end of the experimental teaching: 1) the number of independent statements of the learners meeting the requirements of compliance with the uniform micro-theme has increased; 2) the lexical and grammatical structure of speech has become richer and more diverse; 3) the learners' speech activity has improved; 4) the volume of statements has become half as large again or doubled; 5) the learners began to talk more freely.

The results of the knowledge acquisition test confirmed that the suggested in the paper methodology of formation of foreign-language discursive competence of the bilinguals is efficient.

\section{Conclusion}

All researchers distinguish the communicative function of language and culture, and it is this function that makes culture and language akin. Similarly to cultural studies scholars for culture the linguists for the language acknowledge the function of communication to be the main among others. "Mastering a language is nothing more than the process of acquisition of those operations with words that historically are anchored in their meanings" (Leontiev, 1983). However, previous experience, embodied in objects and words (in the material and spiritual culture) is not given in the direct form; it is just set out in them. Similarly intercultural communication proceeds - mutual understanding of two participants of the communicative act belonging to different national cultures. Having a command of the same language, not always people can understand each other correctly. The reason is in cultural divergence. Two words in two different languages, indicating one and the same thing and being translation equivalents, inevitably happen to be non-identical in content in the cultures of two peoples. Academician L.V. Shcherba wrote at his time: "The world that we are given in our immediate experience, remaining always the same, is perceived differently in different languages, even in those spoken by peoples who represent the known unity in terms of culture perspective (Shcherba, 1974).

L.P. Strelkova indicates the dissimilarity between the words that are quite comparable in the bilingual dictionaries, and are presented as a lexicographical equivalents: "Since two comparable words can be perceived differently by the speakers of the compared languages, it is important to know familiar phrase surroundings, distribution, and the relative frequency of use as well, even of those words which have the same environment" (Strelkova, 1989).

The content of the teaching process should be filled with material that has educational value. Address of the psychologists to various ethnographic and folklore materials (in particular, to Adyghe folktales) allows approaching the study of the peculiarities of the human mentality in the context of a particular unique kind of culture structuring that is characteristic of a particular nation. Being a result, a product of the people's activity, the culture at the same time has the 
opposite effect on the formation of human thought and consciousness; it anchors some forms of regulation of human behavior (Leontiev, 1969). "Culture, likewise language are forms of consciousness reflecting a person's worldview", notes V.N. Teliya (Teliya, 1996).

Teaching foreign language should be focused on entering the culture of the people speaking the studied language and familiarizing the learners with the norms, traditions, realias established in this culture. Alongside, the gift of comparison given by the nature to the human consciousness makes national figurative thinking of different nations comprehensible, and therefore, acquiring the culture of other nationalities in the process of language learning, the student must remain constantly on the soil of native culture.

\section{References}

Barsuk, R.Yu. (1970). Osnovy obucheniya inostrannomu yazyku v usloviyakh dvuyazychiya [Foundations for Foreign Language Teaching in the Conditions of Bilingualism]. - Moscow: Vysshaya Shkola. (P.176). [in Russian]

Baryshnikov, N.V. (2003). Metodika obucheniya vtoromu inostrannomu yazyku v shkole [Methodology of Second Foreign Language Teaching at School]. - Moscow: Prosveshchenie. (P. 159). [in Russian]

Baryshnikov, N.V., Bodoni, M.A. (2008). Didaktika mnogoyazychiya: Teoriya i praktika [Didactics of Multilingualism: Theory and Practice] I/ Inostrannye yazyki v shkole. No. 2. (pp. 22-25). [in Russian]

Belyaeva, M.V. (2009). Tekst kak tsel i sredstvo obucheniya inostrannomu yazyku [Text as Ends and Means for Foreign Language Teaching] // Inostrannye yazyki v shkole. No.7. (pp. 16-21). [in Russian]

Bradford, J.D., Schwartz, D.L. (1999)/ Rethinking transfer: A Smile Proposal with Multiple Implication. Review of Research in Education, 24. (pp. 61-100)

Budagov, R.A. (1988). Kak my govorim i pishem [How We Speak and Write]. - Moscow: Moscow University Press. (P. 220). [in Russian]

Cienki, A. (1997). Semantika v kognitivnoy lingvistike [Semantics in Cognitive Linguistics] // Fundamental trends of modern American Linguistics. Ed. By A. A. Kibrik, et al. - Moscow: MSU press (pp. 340-369). [in Russian]

Dzhandar B.M. (2012). Slozhnoe sintaksicheskoye tseloye v russkom, adygeiskom i angliyskom yazykakh [Complex Syntactic Whole in the Russian, Adyghe and English Languages. - Maykop: Bulleting of ASU. Issue No.2 (99). [in Russian]

Dzhandar, B.M., \& Tuova, M.R. (2007). Old and New Tales of the Caucasus by Kadir I. Natho: Starye I novye skazaniya o Kavkaze: reading book in English (textbook). - Maykop: LLC "Kachestvo". (P. 70). [in Russian]

Galperin, I.R. (1981; 2005). Tekst kak object lingvisticheskogo issledovaniya [Text as an Object of Linguistic Research]. - Moscow: Nauka. (P. 138). [in Russian]

Galperin, P.Ya. (1966). Psikhologiya myshleniya i ucheniye o poetapnom formirovanii umstvennykh deistviy [Psychology of Thinking and Study of Formation Mental Effort]// Issledovaniye myshleniya $v$ Sovetskoy psikhologii. - Moscow. [in Russian]

Galskova, N.D. (2000). Sovremennaya metodika obucheniya inostrannym yazykam [Modern Methodology of Foreign Language Teaching]. - Moscow. (P. 165). [in Russian]

Humboldt, W. (1984). On the Diversity of Human Language Construction and its Influence on the Mental Development of the Human Species // Selected works on linguistics. - Moscow. (pp. 37- 98). [in Russian]

Hut, Sh.Kh. (2003). Adygskoe narodnoye iskusstvo slova [Adyghe Folk Art of Word]. - Maykop: Adyghe Rep. Book House. [in Russian]

Hut, Sh.Kh. (1973). Otrazhenie sotsialnykh otnosheniy v Adygskom volshebnom epose [Reflection of Sotial relations in the Adyghe Magic Epos] // UZ ANNII. - Maykop. (pp. 207-245). [in Russian]

Ilyina, T.A. (1984). Pedagogika. Kurs lektsiy [Pedagogics. Series of Lectures]. - Moscow: Prosveshchenie. (P.496). [in Russian]

Jeremy Harmer (2002). How to Teach English. Pearson Education.

Jeremy Harmer (2004). The Practice of English Language Teaching. Pearson Education.

Kang, J.Y. (2005). Written narratives as an index of L2 competence in Korean EFL learners. Journal of Second Language Writing, 14. (pp. 259-279).

Leontiev, A.A. (1969). Psikholingvisticheskiye edinitsy i porozhdeniye rechevogo vyskazyvania [Psycho-linguistic Units and Generation of Speech Act]. - Moscow: Nauka. (P. 306).

Leontiev, A.A. (1983). Izbrannye psikhologicheskiye issledovaniya [Selected Psychological Studies]. Vol.1. - Moscow: Prosveshchenie. (P.392). [in Russian]

Leontiev, A.A. (1997). Osnovy psikholingvistiki [Foundations of Psycholinguistics]. - Moscow: Smysl. (P.287). [in Russian]

Lurie, C.B.(1998). Istoricheskaya etnologiya [Historic Etnology]. - Moscow: Aspect Press. (P.448). [in Russian]

Mirolyubov, A.A. (2001). Kulturovedcheskaya napravlennost v obychenii inostrannym yazykam [Culturological Orientation in Foreign Language Teaching]// Inostrannye yazyki v shkole. No.5. (pp. 11-15). [in Russian]

Moskalskaya, O.I. (1981). Grammatika teksta [Text Grammar]. - Moscow. (P. 183). [in Russian]

Pomeratseva, E.V. (1965). Sudba russkoy skazki [Fate of Russian folktale] / E.V. Pomeratseva. - Moscow: Nauka. (P.220). [in Russian]

Propp, V.Ya. (2000). Russkaya skazka [Russian folktale]. - Moscow: Labyrinth. (P.335). [in Russian]

Royer, J.M., Mestre, J.P, Dufresne, R.J. (2005). Framing the transfer problem. In J.P.Mestre, Transfer of learning from a modern multidisciplinary perspective. - Greenwich, CT: Information Age Publishing.

Safonova, V.V. (1993). Sotsiokulturnyy podkhod k obycheniyu inostrannomu yazyku kak spetsialnosti [Sociocultural Approach to Foreign Language Teaching as Specialty]: Abstract of Dissertation . ... DSc. - Moscow. (P. 38). [in Russian] 
Sharadzenidze, T.S. (1971). Problemy vzaimootnosheniya yazyka i rechi [Problems of Interrelation of Language and Speech]. - Tbilisi: Metsnshereba. (P. 21). [in Russian]

Shcherba, L.V. (1974). Prepodavanie inostrannykh yazykov v sredney shkole [Foreign Language Teaching at Secondary School]. Moscow: Vysshaya Shkola. (P. 112). [in Russian]

Shchukin, A.N. (2010). Obucheniye inostrannym yazykam: Teoriya i praktika: uchebnoye posobie dlya prepodavateley i studentov [Foreign Language Teaching: Theory and Practice: textbook for teachers and students]. 4thEdition. - Moscow: Filomatis: "Omega-L" Publishing House (P. 480). [in Russian]

Shkhapatseva, M.Kh. (2005). Sopostavitelnaya grammatika russkogo i adygeiskogo yazykov [Contrastive Grammar of the Russian and Adyghe languages]. - Maykop. (P. 328).

Strelkova, L.P. (1989). Uroki skazki [Lessons of the folktale]. - Moscow: Pedagogika. (P. 127). [in Russian]

Teliya, V.N. (1996). Russkaya frazeologiya. Semanticeskyy, pragmaticheskyy i lingvokulturologicheskyy aspekty [Russian Phraseology. Semantic, Pragmatic and Linguoculturological Aspects] - Moscow: "Languages of Russian Culture" School. (P. 284). [in Russian]

Tuova, M.R. (2012). Formirovanie kommunikativnoy kompetentsii uchashchikhcya-adygheitsev v klassakh filologicheskogo profilya [Formation of Communicative Competence of Adyghe Learners in the Philology-oriented Classes](based on the material of Adyghe folktales). - Maykop. (P. 32). [in Russian]

Urakova F.K., Tuova, M.R. (2012). Filologicheskaya podgotovka uchashchikhcya-adygheitsev na osnove vzaimosvyazannogo obucheniya predmetam yazykovogo tsykla: skhodstva i razlichiya v soizuchaemykh yazykakh [Philologic Training of Adyghe Learners Based on Mutually Connected Teaching of Language Cycle Subjects: Similarities and Differences in the Simultaneously Studied Languages // Bulletin of the Adyghe National University. Series 3: Pedagogics and Psykhology. No.4 (109). - Maykop. (pp. 109-120). [in Russian]

Van Dijk, T.A. (1985). Discourse and Communication [Text]. - Berlin: De Gruyter. (pp. 69-93)

Vinogradov, V.V. (1956). Problemy Russkoy stilistiki [Problems of Russian Stylistics] - Moscow: Vysshaya Shkola. [in Russian]

Vygotskyy, L.S. (1996). Myshlenie i rech [Thinking and Speech]. - Moscow: Labyrinth. (P. 415).

Yelizarov, G.V. (2005). Kultura i obucheniye inostrannym yazykam [Culture Foreign Language Teaching]. - St.Petersburg: KARO. (P. 352). [in Russian] 